\title{
Eksplorasi Penguasaan Konsep Fisika pada Materi Kalor dengan Authentic Learning Berbasis Inquiry pada Peserta Didik SMAN
}

\author{
Rizky Ayu Maharani ${ }^{1}$, Lia Yuliati ${ }^{1}$, Nandang Mufti ${ }^{1}$ \\ ${ }^{1}$ Pendidikan Fisika-Universitas Negeri Malang
}

\begin{tabular}{l} 
INFO ARTIKEL \\
\hline Riwayat Artikel: \\
Diterima: $14-05-2019$ \\
Disetujui: $17-11-2019$ \\
\hline
\end{tabular}

Kata kunci:

authentic learning;

inqury;

mastery of concepts;

heat;

authentic learning;

inqury;

penguasaan konsep;

kalor

\section{Alamat Korespondensi:}

Rizky Ayu Maharani

Pendidikan Fisika

Universitas Negeri Malang

Jalan Semarang 5 Malang

E-mail: liayuliatifmipa.um.ac.id

\begin{abstract}
ABSTRAK
Abstract: The purpose of this study is to describe changes in in heat material with authentic learning based- inqury. The samples used in this study were students as many as 28 students. This study used mixed methods with embedded experimental design. Data collection techniques with observations, tests, and interviews. Data analysis through the stages of data reduction, coding, data presentation, and conclusions then with $\mathrm{N}$-gain Score. The results of research is students' understanding of concepts to increase with the category of understanding some concepts.
\end{abstract}

\begin{abstract}
Abstrak: Tujuan penelitian ini yaitu mendeskripsikan perubahan penguasaan konsep peserta didik pada materi kalor dengan pembelajaran authentic learning berbasis inqury. Sampel yang digunakan pada penelitian sebanyak 28 peserta didik. Penelitian ini menggunakan mixed methods dengan desain embedded experimental. Teknik pengumpulan data dengan observasi, tes, dan wawancara. Data dianalisis dengan tahapan reduksi data, coding, penyajian data, dan kesimpulan sekaligus dilengkapi dengan $\mathrm{N}$-gain Score. Kesimpulan penelitian yaitu kemampuan konsep peserta didik mengalami peningkatan dengan kategori memahami sebagian konsep.
\end{abstract}

Penguasaan konsep memberikan pengertian bahwa konsep-konsep yang diajarkan kepada siswa bukanlah sekedar bahan hafalan saja, tetapi konsep itu harus dipahami agar dapat digunakan untuk dapat memecahkan masalah yang dihadapi (Sungkawan, 2013). Pada proses pembelajaran Fisika sebagian besar masih banyak menekankan kegiatan menghafal konsep-konsep atau rumus dan tanpa memberikan kesempatan peserta didik untuk aktif dalam kegiatan pembelajaran Fisika sehingga tidak dapat menumbuhkan sikap ilmiah. Seperti yang diungkapkan oleh beberapa peneliti dimana siswa masih mengalami permasalahan untuk memahami konsep-konsep fisika konseptual diajarkan kepada mereka (Saleh, 2011). Hal ini menyebabkan peserta didik mengalami kesulitan saat memecahkan persamasalan Fisika dikarenakan penguasaan konsep yang rendah. Selama kegiatan belajar berlangsung hendaknya peserta didik dibiarkan mencari atau menemukan sendiri makna segala sesuatu yang dipelajari. Hal ini diperlukan supaya peserta didik dapat lebih mudah dalam mengembangkan kemampuan penguasaan konsep. Penguasaan konsep peserta didik nantinya mampu membantu mereka dalam proses pemecahan masalah yang dihadapi. Pemecahan masalah biasanya didefinisikan sebagai perumusan jawaban baru, melalui aplikasi dalam proses belajar sederhana untuk menghasilkan sebuah solusi (Selçuk \& Çalỳskan, 2008).

Peserta didik dikatakan memiliki kemampuan penguasaan konsep jika mampu menguasai kompetensi dasar yang terdapat pada silabus. Kompetensi dasar dalam materi Fisika, seperti materi Suhu dan Kalor harus dikuasai dan dipelajari oleh peserta didik di seluruh kurikulum di Indonesia pada tingkatan pendidikan SMA dan SMK untuk peminatan IPA ataupun IPS (Kemendikbud, 2013). Materi ini tidak hanya dipelajari di tingkat pendidikan menengah atas, namun juga di tingkat perguruan tinggi. Materi suhu dan kalor merupakan salah satu materi dalam kurikulum yang cukup sulit untuk dipelajari oleh peserta didik. Beberapa buku teks yang digunakan peserta didik memiliki penjelasan yang berbeda mengenai definisi kalor, seperti 'kalor merupakan suatu energi', kalor merupakan wujud dari sebuah energi, kalor berasal dari matahari dan sebagainya (Mustafa Sozbilir, 2015). Materi suhu dan kalor berkaitan langsung dengan lingkungan fisik peserta didik. Oleh karena itu, konsep suhu dan kalor dikembangkan dari interpretasi ide yang didapatkan dari pengalaman sehari-hari peserta didik (Luera, et al., 2005). 
Kesulitan peserta didik dalam mempelajari materi suhu dan kalor masih sering dikarenakan pemahaman konsep yang kurang tentang perbedaan kalor dan suhu, banyak dari peserta didik beranggapan jika suhu dapat diukur dengan sentuhan (Winarti, Cari, Suparmi, Sunarno, \& Istiyono, 2017). Hal ini dikarenakan, peserta didik mengalami kesulitan dalam pemahaman antara pengetahuan konsep fisika dengan fenomena fisika dalam kehidupan sehari-hari. Minimnya pemahaman konsep menyebabkan perserta didik sulit dala memecahkan permasalah fisika khususnya yang berhubungan dengan kehidupan seharihari. Kesulitan yang dialami peserta didik tidak disadari oleh guru pengajar karena proses pembelajaran yang lebih dominan pada teacher centered.

Authentic Learning merupakan strategi pembelajaran yang dirancang untuk terhubung dengan masalah dan aplikasi yang diajarkan pada peserta didik di sekolah ke dunia nyata (Sarah Pearce, 2016). Authentic Learning biasanya berfokus pada dunia nyata, masalah kompleks dan solusi mereka, menggunakan latihan peran-bermain, kegiatan berbasis masalah, studi kasus, dan partisipasi dalam komunitas praktik virtual (Lambordi, 2007). Proses pembelajaran dengan pendekatan Authentic Learning dapat memudahkan peserta didik dalam menganalisis suatu fenomena fisis yang nantinya mampu dijelaskan secara matematis. Peserta didik tidak akan merasa kesulitan ketika fenomena yang diambil merupakan kondisi nyata yang pernah dialami langsung. Hal ini sesuai dengan pendekatan pembelajaran dengan inquiry.

Strategi pembelajaran yang berbasis inquiry merupakan salah satu strategi pembelajaran yang secara efektif melibatkan peserta didik dalam kegiatan penyelidikan. Peserta didik mengumpulkan data melalui observasi, berkesperimen, dan menafsirkan data untuk menyimpulkan suatu konsep dan meningkatkan suatu pemahaman (Nadelson, Callahan, Pyke, Hay, \& Schrader, 2009). Peserta didik terlibat langsung dalam fase siklus inquiry untuk membangun sendiri dalam proses penalaran pada fenomena kehidupan nyata (Pedaste et al., 2015). Pendekatan berbasis Inquiry telah mendapat perhatian yang kuat secara global, berdasarkan manfaat yang dilaporkan yang dapat memberikan pencapaian tujuan pendidikan yang terkait dengan peserta didik (Donnelly et al., 2014), tingkat motivasi (Hwang et al., 2013) serta mengembangkan kemampuan pemecahan masalah dan keterampilan Inquiry (Gillies, et al., 2014). Manfaat lain dalam proses inquiry didukung secara online lab, menawarkan kepada siswa pengalaman belajar yang unik (De Jong et al., 2014). Inquiry berbasis pertanyaan sekarang diakui sebagai metode utama dan juga penting untuk mengembangkan keterampilan yang diperlukan untuk menyelidiki secara ilmiah dalam berbagai macam fenomena. Penggunaan strategi pembelajaran dengan authentic learning yang berbasis inquiry nantinya mampu mengatasi permasalahan dalam proses pembelajaran fisika yaitu penguasaan konsep dan kemampuan pemecahan masalah. Oleh karena itu, peneliti akan menyelidiki kemampuan penguasaan konsep peserta didik pada materi suhu dan kalor dengan menggunakan Authentic Learning berbasis Inquiry di kelas XI MIPA 2 SMAN 1 Dringu.

\section{METODE}

Penelitian ini menyelidiki bagaimana pengaruh strategi authentic learning berbasis inquiry terhadap pemahaman konsep peserta didik dalam materi suhu dan kalor. Rancangan penelitian yang akan dilakukan menggunakan mixed methods dengan desain embedded experimental (Creswell \& Clark, 2007) pada gambar 1. Desain embedded experimental ini merupakan desain penelitian gabungan yang menggunakan proses kualitatif dan proses kuantitatif. Penelitian ini diawali dengan pemberian soal pre-test kemudian dilakukan proses pembelajaran yang dilakukan sebanyak empat kali pertemuan dengan menggunakan Authentic Learning berbasis Inquiry, kemudian peserta didik akan diberikan soal post-test untuk mengetahui penguasaan konsep sesuai pada gambar 2. Instrumen penelitian yang digunakan dalam penelitian ini yaitu silabus dan RPP. Teknik pengumpulan data menggunakan soal uraian pre-test dan post-test, lembar wawancara, dan lembar observasi. Untuk teknik analisis data kuantitatif yaitu dari hasil pre-test dan post-test dilakukan perhitungan skor N-gain. Untuk teknik analisis data kualitatif melalui empat langkah, yaitu (1) reduksi data: memfokuskan pada hal-hal yang penting yang akan dianalisis secara kualitatif. Dari keseluruhan data yang diperoleh, dipilih data terkait dengan penguasaan konsep dan kemampuan pemecahan masalah peserta didik. Dalam hal ini data yang diambil yaitu jawaban peserta didik pada prestest dan posttest; (2) Coding: mengelompokkan jawaban peserta didik kedalam kategori-kategori yang sesuai dengan rubrik penilaian pada tabel 1; (3) penyajian data: menyajikan data dalam bentuk teks yang bersifat naratif dengan menyertakan tabel, gambar, dan grafik agar mudah dipahami; (4) penarikan kesimpulan.

Tabel 1. Rubrik Penilaian

\begin{tabular}{cl}
\hline \multicolumn{2}{c}{ Rubrik Penilaian Kemampuan Penguasaan Konsep } \\
\hline Skor & \multicolumn{1}{c}{ Keterangan } \\
\hline 0 & Peserta didik tidak paham konsep \\
1 & Peserta didik mengalami miskonsepsi \\
2 & Peserta didik hanya memahami sebagian materi \\
3 & Peserta didik paham keseluruhan materi \\
\hline
\end{tabular}


Rubrik Penilaian Kemampuan Pemecahan Masalah

\begin{tabular}{cl}
\hline Skor & \multicolumn{1}{c}{ Keterangan } \\
\hline 0 & Peserta didik tidak menjawab soal \\
2 & Peserta didik memahami konsep dengan menjawab benar \\
4 & Peserta didik memahami konsep dengan menjawab benar, namun belum memberikan alasan berdasarkan konsep fisika \\
6 & Peserta didik memahami konsep dengan menjawab benar, memberikan alasan namun tidak tepat dengan konsep \\
8 & Peserta didik memahami konsep dengan menjawab benar, memberikan alasan dengan tepat konsepnya \\
10 & Peserta diidik memahami konsep dengan menjawab benar, memberikan alasan dengan konsep dan menunjukkan \\
& persamaan fisikanya
\end{tabular}

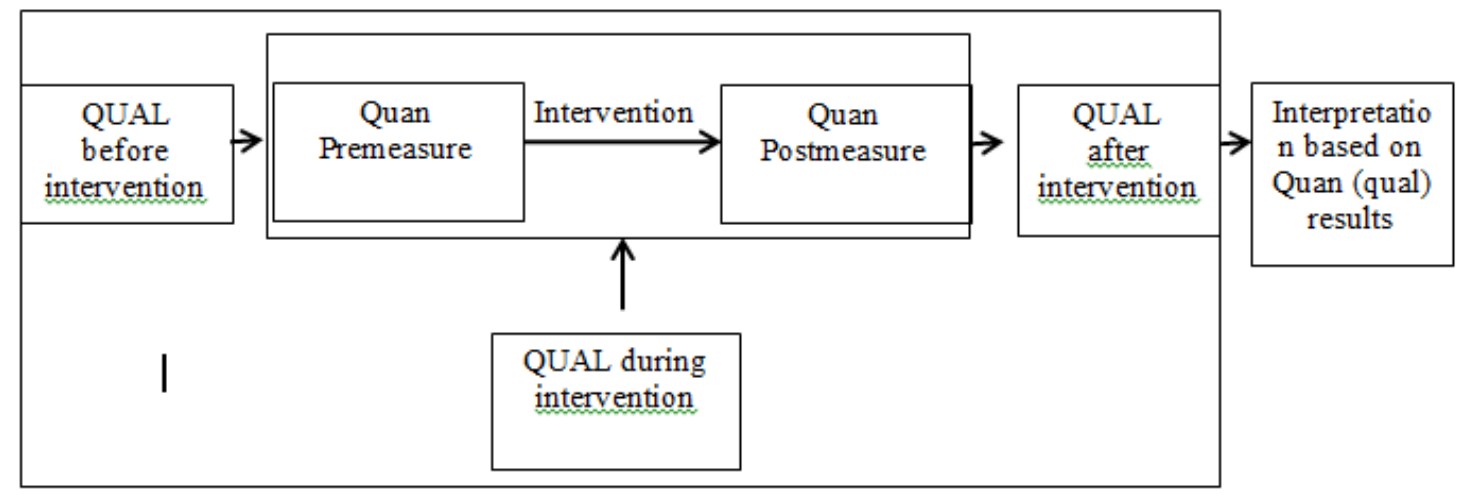

Gambar 1. Desain Embbeded Experimental (Creswell \& Clark, 2007)

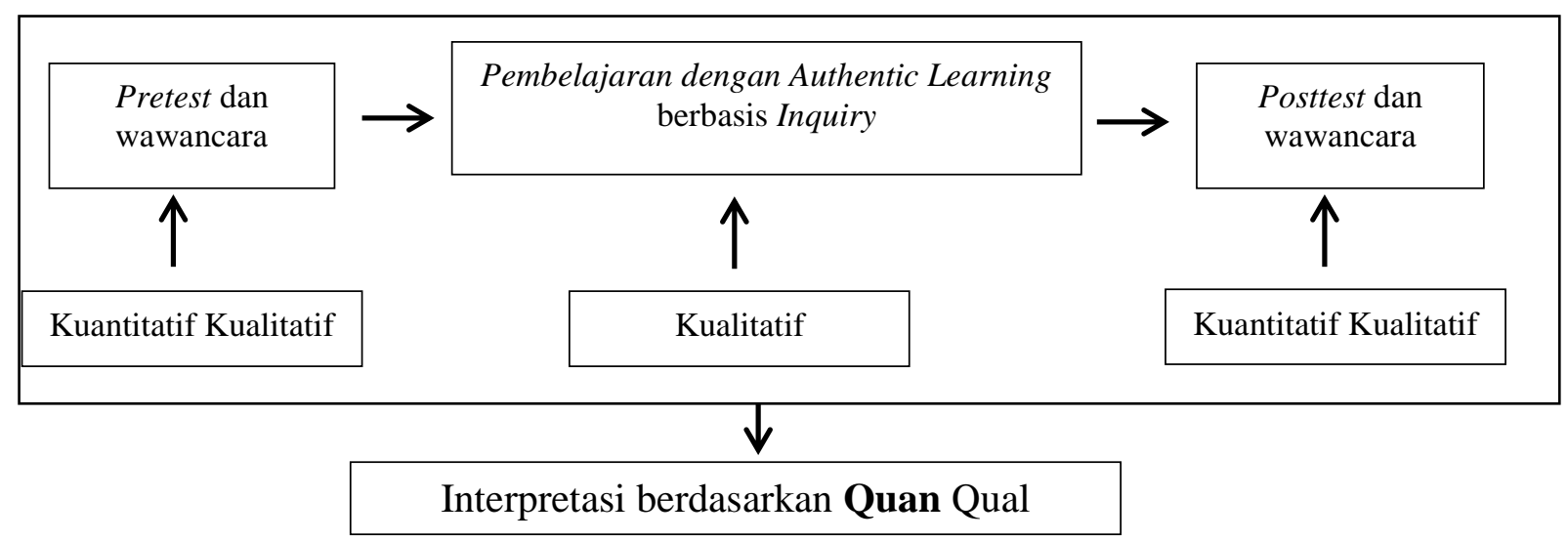

Gambar 2. Desain Penelitian

HASIL

Data kuantitatif pada penguasaan konsep peserta didik diperoleh dari skor hasil pre-test dan post-test. Data kuantitatif hasil pre-test dan post-test peserta didik ditunjukkan pada tabel 1.

Tabel 1. Hasil Pre-test dan Post-test Penguasaan Konsep Peserta Didik

\begin{tabular}{lllllc}
\hline & N & Min & Max & Mean & N-Gain \\
\cline { 1 - 4 } Pre-test & 28 & 2 & 10 & 6,64 & 0,69 \\
\hline Post-test & 28 & 10 & 15 & 12,46 & \\
\hline
\end{tabular}

Berdasarkan data Tabel 4.1 terlihat jika nilai rata-rata pre-test dan post-test yang berbeda dengan nilai pre-test lebih rendah daripada nilai post-test. Hasil pre-test dan post-test dilakukan uji normalitas. Uji normalitas pada hasil pre-test dan post-test dihitung dengan menggunakan SPSS 16.0. Nilai signifikan pada hasil pre-test diperoleh sebesar 0,06 dan hasil posttest sebesar 0,373, yang keduanya lebih besar daripada 0,05 dan disimpulkan jika data terdistribusi normal. Perubahan penguasan konsep peserta didik pada materi kalor dapat diketahui melalui nilai rata-rata peningkatan normalized gain (n-gain) menggunakan bantuan Ms. Excel diperoleh sebesar 0,69. Nilai rata-rata peningkatan normalized gain (n-gain) tersebut masuk 
dalam kategori sedang. Kesimpulan yang didapatkan dari perhitungan dapat dinyatakan bahwa pembelajaran dengan authentic learning berbasis inqury memberikan dampak yang signifikan dalam meningkatkan penguasaan konsep peserta didik pada materi kalor. Perubahan penguasan konsep peserta didik pada materi kalor dideksripsikan dalam data kualitatif melalui analisis jawaban tes penguasaan konsep peserta didik.

Peningkatan penguasaan konsep pada soal pada sub materi hubungan kalor dengan waktu pemanasan dengan rata-rata n-gain sebesar 0,76 yang termasuk kategori tinggi. Pada saat menjawab pertanyaan soal post-test, peserta didik telah mampu menerapkan konsep kalor. Peserta telah memahami hubungan tiap besaran yang memperngaruhi kalor. Hal ini didukung oleh hasil wawancara yang menjelaskan bahwa peserta didik mampu menjawab dikarenakan mengingat konsep dengan mudah karena dilakukannya pembelajaran yang rinci dan bertahap dengan pemberian masalah yang berhubungan dengan konsep fisika. Serta, masalah yang disajikan dihubungkan dengan konsep sehingga memudahkan peserta didik dalam memahami rumus fisika yang ada. Berikut ini peningkatan penguasaan konsep pada beberapa sub materi dengan rata-rata n-gain pada tabel 2.

Tabel 2. Hasil rata-rata n-gain

\begin{tabular}{lcc}
\hline \multicolumn{1}{c}{ Sub Materi } & n-gain & Kategori soal \\
\hline hubungan kalor dengan waktu pemanasan & 0,76 & Tinggi \\
hubungan kalor dengan kalor jenis zat & 0,79 & Tinggi \\
hubungan kenaikan suhu dengan kalor jenis & 0,54 & Sedang \\
hubungan kapasitas kalor dengan massa benda & 0,33 & Sedang \\
pemuaian & 0,33 & Sedang \\
\hline
\end{tabular}

Berdasarkan tabel 2 menjelaskan jika peserta didik mengalami peningkatan penguasaan konsep pada sub materi hubungan kalor dengan kalor jenis zat dengan kategori tingkat tinggi. Hal ini dikarenakan skor pre-test dan post-test mengalami peningkatan pemahaman. Melainkan, mereka akan disajikan beberapa masalah yang mengantarkan mereka untuk menemukan dan merumuskan persamaan fisika yang mendukung masalah tersebut. Selain itu, dengan adanya kegiatan demontrasi dan praktikum membuat peserta didik menjadi merasa nyaman serta mampu mengaplikasikan konsep fisika yang ada. Kegiatan ini disesuaikan dengan kebutuhan "partisipatif peserta didik" yang harapannya untuk menjadikan peserta didik menjadi aktif (Marilyn, 2007). Berikut presentasi hasil skor pre-test dan post-test sesuai sub materi soal pada gambar 3a dan 3b.

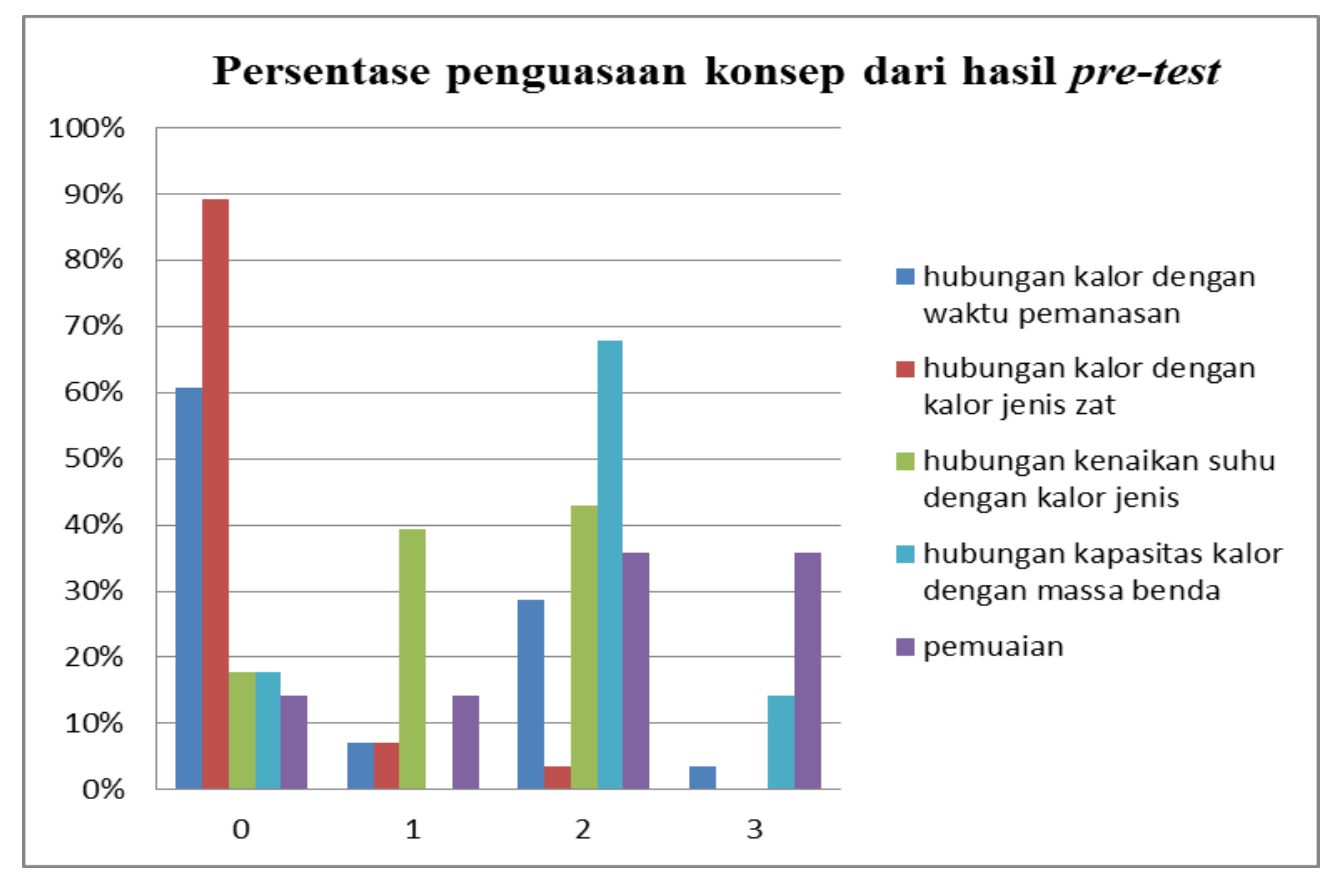

Gambar 3a. Persentase Hasil Pre-Test 


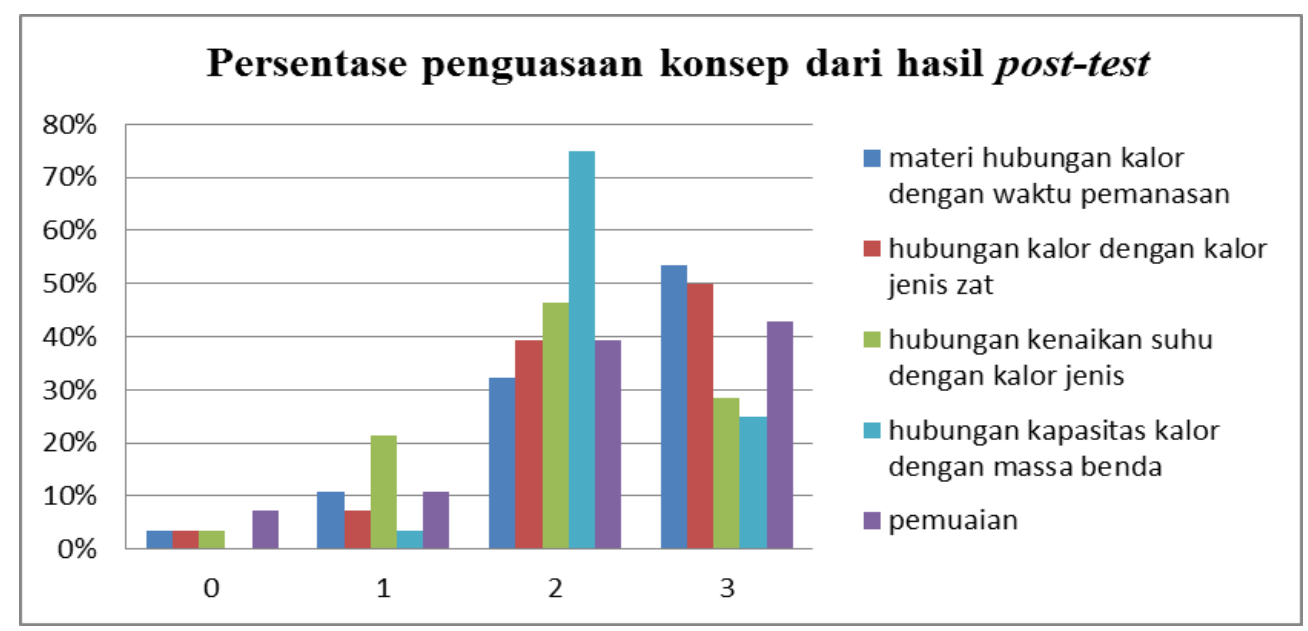

Gambar 3b. Persentase Hasil Post-Test

\section{PEMBAHASAN}

Berdasarkan tabel 2 menjelaskan jika peserta didik mengalami peningkatan pemahaman konsep pada sub materi materi hubungan kalor dengan kalor jenis zat. Pada soal menjelaskan kenaikan suhu tertinggi pada zat alkohol, raksa, dan es dengan kalor yang diberikan dan massa ketiganya sama. Serta peserta didik diminta menggambarkan grafik hubungan perubahan suhu dengan jenis zat (kalor jenis zat). Pada saat pengerjaan soal pre-test, peserta didik belum mengetahui konsep yang diterapkan pada soal sehingga banyak peserta didik yang memilih tidak menjawab soal. Sementara itu, setelah pemberian materi dengan pembelajaran authentic learning berbasis inquiry penguasaan konsep perserta didik meningkat. Hal ini terlihat pada tabel 3 yang menunjukkan perubahan persentase yaitu terdapat $50 \%$ peserta didik telah mampu menjawab dengan benar dan mampu menjelaskan bagaimana hubungan kalor jenis zat dengan perubahan suhu zat tersebut serta mampu menggambarkan grafik hubungannya. Terlihat di awal tes terdapat $89 \%$ peserta didik tidak mampu menjawab soal. Berikut jawaban peserta didik pada gambar 4.

Tabel 3. Perubahan Konsep Soal Nomor 2

\begin{tabular}{|c|c|c|c|}
\hline Skor & Kategori Penilaian Penguasaan Konsep & Pre-test (\%) & Post-test (\%) \\
\hline 3 & Paham Keseluruhan (PK) & 0 & 50 \\
\hline \multirow[t]{2}{*}{2} & Peserta didik mampu menjawab dengan benar dan mampu menjelaskan bagaimana hubungan & 4 & 39 \\
\hline & & 7 & 7 \\
\hline 1 & Paham Sebagian (PS) & & \\
\hline 0 & $\begin{array}{l}\text { Peserta didik mampu menjawab dengan benar tapi tidak dapat menjelaskan bagaimana hubungan } \\
\text { hubungan kalor jenis zat dengan perubahan suhu zat tersebut serta tidak mampu menggambarkan } \\
\text { grafik hubungannya. }\end{array}$ & 89 & 4 \\
\hline & Spesifik Miskonsepsi (SM) & & \\
\hline & Peserta didik menjawab namun salah tidak sesuai konsep & & \\
\hline & Tidak paham (TP) & & \\
\hline & Peserta didik tidak menjawab & & \\
\hline
\end{tabular}

2. Alkohol dengan kalor jeors $(C)=2.400 J / \% \mathrm{C}$ akan mosgalami keraikan suru paling beses.

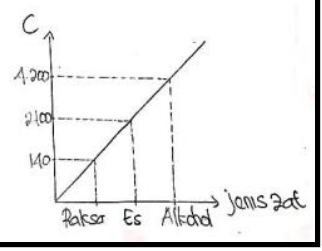

Gambar 4a. Jawaban Soal, Jawaban Miskonsepsi 


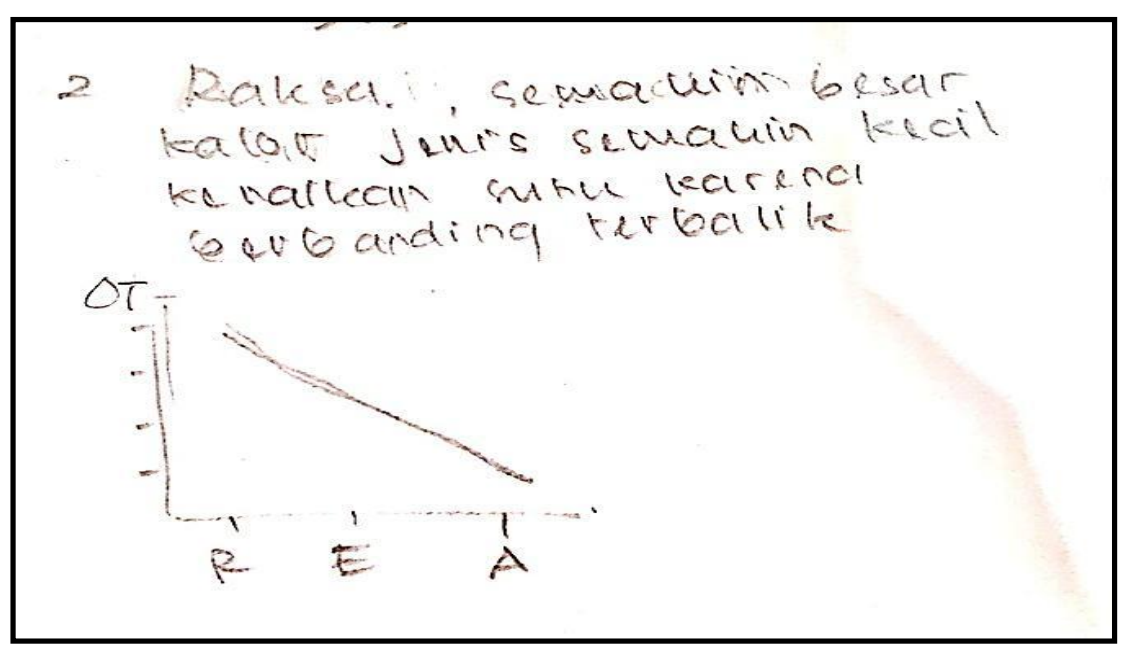

Gambar 4b. Jawaban Soal, Jawaban Benar

Pada soal hubungan kalor dengan kalor jenis zat, peningkatan ditunjukkan dengan rata-rata n-gain sebesar 0,79\% yang termasuk kategori tinggi. Analisis jawaban post-test peserta didik pada gambar 3 menunjukkan peserta didik mengalami miskonsepsi. Berdasarkan hasil wawancara yang dilakukan, peserta didik beranggapan jika kalor jenis dan kenaikan suhu memiliki hubungan yang linear. Hal ini menyebabkan konsep peserta didik beranggapan jika zat dengan kalor jenis yang besar, maka kenaikan suhunya juga akan besar. Peserta didik juga mengalami kesulitan dalam menggambarkan grafik khususnya pada penempatan besaran pada sumbu-x dan sumbu-y sehingga grafik yang dihasilkan berupa hubungan antara kalor jenis dengan jenis zat.

Perolehan skor yang mengalami peningkatan disebabkan oleh pemahaman peserta didik terhadap materi yang baik. Hal ini berkaitan dengan kegiatan pemebelajaran yaitu guru memberikan apersepsi berupa pemahaman awal mengenai kalor dengan menampilkan video berisi pengukuran suhu air dengan menggunakan dua termometer yang berbeda secara bersamaan yaitu termometer alkohol dan raksa. Ternyata ketika dilakukan pengukuran dengan selang waktu yang sama, termometer keduanya menunjukkan skala ukur yang berbeda. Hal ini akan memberikan pengetahuan yang mendalam karena permasalahan yang diangkat hal yang konkret nyata dikehidupan sehari-hari. Selain masalah diapersepsi, pada tahapan inkuiri peserta didik akan disajikan masalah serupa yaitu menampilkan tiga gambar balok es dengan jumlah (volume) yang berbeda. Kemudian guru menanyakan "ketiga balok es manakah yang membutuhkan kalor lebih lama untuk mecair?". Hampir semua peserta didik dapat menjawab jika gambar balok es dengan jumlah terbesar akan membutuhkan kalor lebih banyak. Kemudian guru menghubungkan masalah pertama dengan yang kedua "apakah ada perbedaan masalah diawal dengan yang kedua?". Selain kegiatan belajar tersebut, peserta didik akan dilatih menyelasaikan permasalan dengan diskusi berdasarkan LKPD. Pada LKPD, peserta didik akan menemukan permasalahan yang memicu mereka untuk mampu menggambarkan grafik hubungan dengan benar sehingga pada saat post-test, banyak peserta didik terlihat tidak menemukan kendala.

Pada saat pengerjaan soal pre-test menunjukkan peserta didik mengalami miskonsepsi terlihat pada gambar 4. Peserta didik beranggapan jika kalor jenis dan kenaikan suhu memiliki hubungan yang linear. Hal ini menyebabkan konsep peserta didik beranggapan jika zat dengan kalor jenis yang besar, maka kenaikan suhunya juga akan besar. Peserta didik juga mengalami kesulitan dalam menggambarkan grafik khususnya pada penempatan besaran pada sumbu-x dan sumbu-y sehingga grafik yang dihasilkan berupa hubungan antara kalor jenis dengan jenis zat.

Hasil analisis data yang telah dipaparkan pada bab empat telah menunjukkan bahwa penguasaan konsep peserta didik mengalami peningkatan pada saat post-test. Dikarenakan hasil penguasaan konsep saat post-test lebih tinggi daripada pre-test. Selain terlihat pada hasil perhitungan skor test, juga diperoleh dari hasil wawancara. Hasil wawancara yang dilakukan pada beberapa peserta didik menjelaskan jika pemahaman konsep mereka lebih meningkat karena kegiatan pembelajaran yang dilakukan tidak sekedar menghafal rumus-rumus Fisika. Melainkan, mereka akan disajikan beberapa masalah yang mengantarkan mereka untuk menemukan dan merumuskan persamaan fisika yang mendukung masalah tersebut. Elemen penting dari pengembangan kemampuan penguasaan konsep peserta didik yang dapat melekat adalah dengan pembelajaran nyata yaitu dengan konteks lingkungan sehari-hari peserta didik (Elliott, 2007).

Selain itu, dengan adanya kegiatan demontrasi dan praktikum membuat peserta didik merasa nyaman dan mampu mengaplikasikan konsep fisika yang ada. Eksperimen atau praktikum dianggap sebagai metode dan proses penting untuk memahami fenomena ilmiah dan menyelidikinya lebih lanjut dengan prinsip-prinsip ilmiah (Liu, 2015). Kegiatan ini disesuaikan dengan kebutuhan "partisipatif peserta didik" yang harapannya untuk menjadikan peserta didik menjadi aktif. 
Seringkali peserta didik masih mengalami permasalahan dalam memahami konsep-konsep fisika konseptual yang diajarkan kepada mereka (Saleh, 2011). Dengan diimplementasikannya kegiatan pembelajaran authentic learning berbasis inquiry efektif mampu meningkatkan penguasaan konsep peserta didik. Pembelajaran yang efektif jika pembelajaran tersebut dapat mengembangkan perubahan konsep ke arah yang lebih bermakna (Suparno, 1999). Pembelajaran authentic learning berbasis inquiry memberikan pengalaman belajar yang lebih pada peserta didik. Hal ini timbul karena adanya kegiatan praktik langsung dan adanya penerapan prinsip-prinsip umum berdasarkan materi yang sedang dipelajari sehingga tumbuh rasa kreativitas, kritis, dan mendorong kerja sama antar peserta didik (Ika et al. 2017). Hal ini didukung penelitian yang dilakukan oleh (Rule. 2006) yang menjelaskan bahwa pembelajaran authentic yang melibatkan peserta didik dalam masalah penyelidikan masalah nyata dapat melatih keterampilan berpikir dan memberdayakan peserta didik untuk meningkatkan penguasaan konsep. Selain itu, penelitian lain yang menjelaskan jika authentic learning berbasis masalah efektif mampu meningkatkan kemampuan berpikir kritis peserta didik (Yuliati, 2018). Kemampuan berpikir kritis tingkatkan kemampuan yang lebih tinggi daripada penguasaan konsep. Dengan demikian, authentic learning sangat efektif jika digunakan untuk meningkatkan kemampuan penguasaan konsep peserta didik.

\section{SIMPULAN}

Berdasarkan hasil dan pembahasan yang telah dipaparkan dapat disimpulkan bahwa model authentic learning berbasis inquiry berpengaruh terhadap penguasaan konsep peserta didik kelas XI MIPA 2 SMAN 1 Dringu. Adapun saran penelitian ini dapat digunakan dan diterapkan sebagai referensi pembelajaran dalam meningkatkan penguasaan konsep peserta didik. Untuk penelitian selanjutnya dapat menggunakan variasi soal pilihan ganda yang beralasan untuk memudahkan peserta didik menjawab soal. Peneliti lain dapat menerapkan pembelajaran ini untuk variabel kemampuan dan materi fisika lainnya.

\section{DAFTAR RUJUKAN}

De Jong, T., Linn, M. C., \& Zacharia, Z. C. (2013). Physical and Virtual Laboratories in Science and Engineering Education. Science, 340 (6130),

Donnelly, D. F., Linn, M. C., \& Ludvigsen, S. (2014). Impacts and Characteristics of Computer-Based Science Inquiry Learning Environments for Precollege Students. Review of Educational Research, 84(4),

Gillies, R. M., Nichols, K., Burgh, G., \& Haynes, M. (2014). Primary Students' Scientific Reasoning and Discourse During Cooperative Inquiry-Based Science Activities. International Journal of Educational Research. 63.

Hwang, G. J., Wu, P. H., Zhuang, Y. Y., \& Huang, Y. M. (2013). Effects of the Inquiry Based Mobile Learning Model on the Cognitive Load and Learning Achievement of Students. Interactive Learning Environments, 21(4).

Ika, K., Dwi, Y., \& Sugianto. (2017). Bahan Ajar Berbasis STEM (Science, Technology, Engineering, and Mathematics) untuk Meningkatkan Penguasaan Konsep Siswa SMA. Unnes Physic Education Journal, 6(3), $53-58$.

Liu, D. (2015). Integration of Virtual Labs into Science E-Learning. Procedia Computer Science, 75(3), 95-102.

Rule, A. C. (2006). The Components of Authentic Learning. Journal of Authentic Learning, 3(1), 1-10.

Selçuk, Gamze Sezgin., \& Serap Çalỳskan. (2008). The Effects of Problem Solving Instruction on Physics Achievement, Problem Solving Performance and Strategy Use. American Journal of Physics Education, 2(3), 1.

Sozbilir, M. (2015). A Review of Selected Literature on Students' Misconceptions of Heat and Temperature. Boğaziçi University Journal of Education, 20(1), 25-41.

Sungkawan, R. 2013. Analisis Penguasaan Konsep Awal Fisika pada Pembelajaran Menggunakan Model Advance Organizer Berbasis Eksperimen terhadap Hasil Belajar Fisika. Jurnal Pendidikan Fisika, 2(2), 73-80.

Winarti, C., Suparmi., Sunarno., W., \& Istiyono, E. (2017). Development of Two Tier Test to Assess Conceptual Understanding in Heat and Temperature. Journal of Physics: Conference Series 795: 012052.

Yuliati, L., Fauziah, R., \& Hidayat, A. (2018). Student's Critical Thinking Skills in Authentic Problem Based Learning. IOP Conf. Series: Journal of Physics: Conf. Series 1013 (2018) 012025. doi :10.1088/1742-6596/1013/1/012025 